\title{
An Approach to Report Writing in the World of Work
}

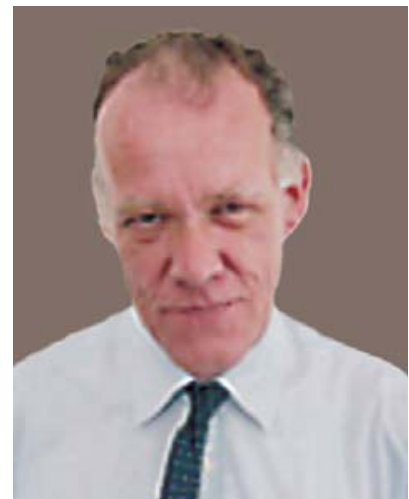

Andy Keedwell

$\mathbf{M}$ y experience has been very much that of training English Language learners in the world of work the field which is commonly called EOP - English for Occupational Purposes. To provide some examples, this experience has included developing English Language skills with Cambodian NGO workers, working for the International Labour Organisation whose job it is to obtain information on likely locations for investment, Sudanese experts from the Ministry of Justice who are carrying out an in-depth inspection of their country's prisons, Russian engineers, working on an offshore oil platform who are concerned about the installation of fire safety systems, and Armenian junior diplomats based in Minsk who are reporting back on economic developments in the country. These rather varied examples have been chosen as in each case, once outside the classroom or training room, students were expected to detail their findings, research and recommendations in the form of a report. Here, I will suggest that the writing skills and especially the report writing skills we aim to develop in the world of EOP are significantly similar to those which university lecturers aim to develop in the field of EAP - English for Academic Purposes. Both sides, I feel, have a great deal to learn from each other and I hope that the approach to report writing outlined here is of help both to EOP and EAP practitioners. An ability to construct clear, concise and readable reports is of the utmost value to a huge range of English language learners, working in a breathtaking range of work situations. Worldwide, international organisations are keen to develop the skills of 'national' employees - and national organisations are keen to develop links with the wider world. These organisations might include large multi-national companies - an oil company for example where many different disciplines demand report writing skills. An ability to write reports for a non-native speaking member of a company such as this opens doors! It might include a small struggling non-governmental organisation which has made measurable progress in remote rural areas and needs to document its progress. It might also include an institution such as British Council itself where, in an Armenian context, report writing is a major activity for each of the project managers, working here, each in a different sphere. Thus to some extent, then, an ability to produce reports leads to sustainability and in its own way plays a part in empowerment.

As in all aspects of English language learning, it is perhaps never too soon to start I suggest here that these report writing skills can be developed before entry into the workplace, at university, as well as an important part of university based activities such as research. 
It is attractive to view the development of report writing skills as figuring more at the training end of the spectrum than at the educational end, as proposed by H.G.Widdowson (1983, p.6). It is a type of training that leads to what the linguist has called restricted competence. By its nature, report writing produces what A.Mountford has called predictable and prescribable language (1988, p.78). A good report is produced according to accepted norms and standards and these norms and standards in English can be taught, regardless of the extent to which report writing formats vary from one language to another. A.M.Johns (1990, p.32) talks of rules of discourse, which are standards by which a native speaker will produce a discourse such as a report, bearing in mind accepted standards of clarity, acceptability and appropriacy which meet the reader's expectations. Report writing is a routine, and these routines can be learnt.

In order to support learners in writing a report, we need to first of all determine the features of a report and, in particular, those features which might prove problematical to our learners. Clearly, a report is goal based - it aims to get something done. It is purposeful and sets out to be a basis for action, whether that action is the correct siting of a new fire escape, the launch of a new product on the market or the implementation of funding for a teacher training programme. A report may be both informational and persuasive (Britton J., 1975, p.99). It often aims both to provide information and to persuade the reader to follow a particular course of action through recommendations.

It may be useful as a rule of thumb to categorise reports into the following groups, although obviously there may be overlap between categories.

- An investigation which has found something out.

- A survey which has found out what people think.

- An evaluation or review which has found out how well something or somebody is working.

- A feasibility study which has decided how well something will work in the future.

- A plan which gives details of what an organisation will do in the future.

Regardless of detailed content or context, the majority of reports would appear to share the significant characteristics of one of these types or another. When for example, engineers from Armenia Airways are giving information on whether a new kind of plane should be used by the company, they are working on a type of feasibility study. An organisation describing if a new way of interviewing new staff has been successful are fundamentally evaluating. Familiarity with these report types will enable writers to adjust their language to the appropriate format. A second view of report-writing which has been found to be of use to students is to see the report writer as a lawyer arguing for or against a case. Both lawyer and report writer have to:

- organise language to present ideas;

- give information clearly;

- include all-important information while excluding information which is not important; 
- make recommendations with clear reasons, and persuade;

- show why opposing recommendations should not be followed.

Before embarking on the design of a report writing course, we need to have undertaken a thorough needs analysis, which in most cases will take one or more of three forms: a genre analysis, a deductive needs analysis or an inductive needs analysis. Any designer of a report writing course will find an extensive investigation of the genre of the particular report type his or her students are or will be expected to write enormously rewarding. Definitions of a genre hinge on the fact that exponents of a genre share a communicative purpose and share some or all characteristics of structure, style, content and intended audience. (Swales J., 1990, p.45). A report is an example of a distinct genre, and has distinctive linguistic features which characterise it as one. A genre will be characterised by:

\section{A micro-structure:}

For example, the structural characteristics of a research paper as investigated by Swales included:

- Abstract

- Introduction

- Method

- Results and discussion.

A range of micro-functions:

Trimble and the Washington School identified a range of rhetorical functions and techniques which may include, in the case of a report:

- Classifying

- Comparing and ordering

- Exemplifying

- Making relations between text and illustration.

In undertaking a genre analysis, we need to ask focused questions.

These might include:

- How is a report usually organised?

- How are aims usually expressed?

- How does the writer commit to a certain idea - are there any degrees of commitment?

- How frequently do writers use the passive in a typical report?

- How does the writer usually express recommendations?

To support the design of a report writing course, I examined a wide range of reports from the workplace, primarily reports which could be described as looking backward. 
Findings show that these reports are usually composed of sections, on a similar basis to Swales' research articles. These sections might have different names, depending on the type of report, but almost always include:

- An introduction which sets out the aim.

- A method section which describes how an investigation was undertaken usually sequentially.

- A results section which presents data, with or without discussion of the data.

- A recommendation section in which proposals of some kind are made.

A typical introduction will outline the aim of a report, often either focusing on the aim or on the report itself as subject:

\begin{tabular}{|l|l|l|}
\hline This report & aims to & identify different areas of occupation in Aspatria \\
\cline { 1 - 1 } The aim of this report & is to & and to make recommendations on the funding of \\
\cline { 1 - 1 } The objective of this report & is to & small businesses in the republic \\
\hline
\end{tabular}

It is very atypical in English to express an aim as 'This report aims to.......' as it implies that an attempt will be made which may or may not be successful.

A range of verbs in the infinitive clause are used. Thus, for example,

\begin{tabular}{|c|c|c|c|}
\hline $\begin{array}{l}\text { o identify } \\
\text { o classify }\end{array}$ & $\begin{array}{l}\text { to recommend } \\
\text { to outline } \\
\text { to determine }\end{array}$ & $\begin{array}{l}\text { to examine } \\
\text { to evaluate } \\
\text { to review }\end{array}$ & $\begin{array}{l}\text { to analyse } \\
\text { to assess }\end{array}$ \\
\hline
\end{tabular}

Introductions often follow a problem/solution pattern (Hoey, 1983) or more precisely, a problem, purpose and scope pattern.

- The problem outlines the situation which led to the production of the report.

- The purpose explains what the report is setting out to do.

- The scope includes what will and will not be included, and, frequently, where further information can be found.

In the Method section, the writer almost always highlights steps: through sequences, and through staging. But surprisingly, the active is used almost as frequently as the passive - so an engineer writing a technical report might say:

The oil stream is directed through the main oil pump of a centrifuge.

or

A centrifuge directs the oil stream through the main oil pump. 


\section{Results:}

In the results section, the writer uses an impersonal style and thematises results:

\begin{tabular}{|l|l|l|}
\hline The survey & Reveals & That \\
\hline The analysis & Indicates & That \\
\hline The survey data & Show & That \\
\hline The totals for both of these groups & Reflect & That \\
\hline
\end{tabular}

Many writers need to classify and to compare.

Classification can be complex as shown by the example below from an International Labour organisation report:

\begin{tabular}{|l|l|}
\hline Agriculture is the main occupation & General statement \\
\hline $\begin{array}{l}\text { Cultivators may be classified into different strata } \\
\text { according to size and income }\end{array}$ & $\begin{array}{l}\text { Setting up terms for } \\
\text { categorization }\end{array}$ \\
\hline Table 9.2 clearlyreveals & Reference to specific figures \\
\hline $\begin{array}{l}\text { Some may be technically landless, others may be } \\
\text { actually landless }\end{array}$ & $\begin{array}{l}\text { Classifying as further sub } \\
\text { groups }\end{array}$ \\
\hline
\end{tabular}

The writer may often hedge, because not all facts are clear:

It is also difficult to obtain data on...

In the absence of reliable information on age conditions, it is not feasible to...

It has not proved possible to discover the real incomes of...

\section{Recommendations:}

In a typical sample these results have been found.

Not surprisingly, recommendations use modal verbs.

\begin{tabular}{|l|l|l|}
\hline & Active & Passive \\
\hline should & 55 & 22 \\
\hline Might & 7 & 4 \\
\hline Could & 6 & 4 \\
\hline Must & 2 & 1 \\
\hline
\end{tabular}


Recommendations also often use an impersonal it to express suggestions, e.g.:

\begin{tabular}{|l|l|l|}
\hline It is & recommended & that \\
\hline & suggested & \\
\hline & proposed & \\
\hline & advisable & \\
\hline
\end{tabular}

A ‘quick and dirty' genre analysis of this kind can:

- show us how a typical writer in this genre will express purpose;

- show us typical forms of organization which learners need to be àble to manipulate;

- give us information on appropriate registers: formality and informality of typical texts;

- provide information on particular grammatical structures which learners will need to be able to use;

- provide us with examples of lexical choices, commonly made by writers in the particular genre.

\section{Needs Analysis:}

It is helpful to think about needs analysis in terms of needs, lack and wants. (Hutchinson T., Waters A., 1987, p.56)

Deductive analysis (Berwick M., 1989, p.58)

The EOP needs analyst depends very much on the use of questionnaires, which need to target:

- $\quad$ target level performance of the learner (Munby J.L., 1978, p.12);

- when English is used by the target learners and in which types of situations;

- the frequency with which language is used;

- how English is used - for which skills and in which genres of writing;

- what tasks in English the learner is expected to perform now and what tasks they are expected to perform after the course, after promotion, for example;

- the learners' own assessment of the language skills;

- if learners have previous experience of classroom lessons, forms of self-access learning, ESP, etc.

It is not only the learner whom we need to target by needs analysis but also the sponsors of the course, the learner's employers and other agencies.

- What is their assessment of the learner's skills?

- Which language skills do they think are essential or desirable for the learner?

- Which language tasks do they expect their learners to be able to perform and to what degree? 
Inductive methods of needs analysis:

An inductive needs analysis involves watching the learner on the job. This might be limited by time, feasibility, confidentiality and logistics. In designing a report writing course for oil engineers, I was lucky enough to spend three months living on an off-shore oil platform - but this was the exception rather than the rule!

\section{Report writing - meeting the students' needs:}

In my opinion, errors in learners' writing at upper intermediate level and above involve far more than just accuracy in grammar and vocabulary and a traditional approach to 'mistakes'. M. Hoey (1983) emphasises that reading is a dialogue between reader and writer. Non-native report writers often make demands which are too heavy on native speakers because they violate one or more rules of discourse. And good reports are written to be read in a hurry.

The report writer needs to be aware that he or she is only writing to meet the readers' needs and to answer a series of questions which the reader has. The writer needs to answer each of these questions about the reader at the planning stage:

1. What information does the reader need to find out?

2. Is the reader interested in your recommendations?

3. What facts and figures do they need?

4. How much does the reader know about this topic already?

5. Is the reader a general reader or a specialist? Will the reader understand specialist terms and expressions?

6. What will the reader do after he or she has read the report? What change will it result in?

A number of exercises can be developed by the course designer in order to draw students' attention to questions the report reader is likely to formulate and how the report writer may answer them.

In my experience, students have also found four basic principles of report writing very useful. A useful acronym is COPE - because these four principles will assist the student to cope with report writing. The four principles are:

- Clarity - Helping the reader by being clear;

- Organisation - Ordering and structuring your report so it is easy to follow;

- Precision - Using language that has an exact meaning;

- Economy - Not using more words than necessary to communicate your meaning.

A report writing trainer needs the flexibility and initiative to refer back to these four principles at each and every opportunity. If we take COPE as set of principles, we can see that an effective writing course needs to include all of these areas. 


\section{Organising a report:}

- focus on the structure of a typical report;

- enabling students to identify the purpose of particular paragraphs of a report (authentic or adapted);

- enabling students to identify the purpose of particular sections of a report (authentic or adapted);

- familiarising learners with the problem, purpose and scope in introductions.

\section{Organising internal coherence and cohesion:}

Topic sentence activities - matching topic sentences and producing topic sentences for supplied paragraphs.

\section{Being precise:}

- expressing clearly which sections of the report are fact and which are opinion;

- using language precisely to describe an existing situation;

- using language precisely to describe change;

- developing an ability to write formally and informal as appropriate activities which include converting informal language into formal language and vice versa;

- using technical vocabulary efficiently, but more importantly, using sub-technical vocabulary effectively.

\section{Economy:}

- stating exactly what is needed - no more and no less;

- developing an ability to distinguish what implies 'hot air' in a text - breaking away from 'Soviet' traditions of using many words to say nothing;

- manipulating micro-functions of sequencing, referring to diagrams, comparing. classifying etc. effectively, often through converting verbal data to non verbal data and vice versa (Nuttall C., 1982, p.52).

Above all, we need to focus on developing the skills of a learner as a mechanic of language - and throughout guaranteeing clarity.

\section{References:}

1. Berwick, M. Needs Assessment in Language Programmes, from Theory to Practice. In: The Second Language Curriculum ed.by Johnson, R.K. Cambridge, Cambridge University Press, 1989. 
2. Britton, J. The Development of Writing Abilities. London, Macmillan, 1975.

3. Hoey, M. On the Surface of Discourse. London, Allen and Unwin, 1983.

4. Hutchinson, T.; Waters, A. English for Specific Purposes: a Language Centered Approach. Cambridge, Cambridge University Press, 1987.

5. Johns, A.M. Composition Theories. In: Knoll, B. Second Language Writing: Research Insights for the Classroom. Cambridge, Cambridge University Press, 1990

6. Mountford, A. Factors Influencing ESP Materials Production and Use. In: Chamberlain, D.; Baumgardner, R.J. ESP in the Classroom. ELT Documents 128, London, MEP, 1988.

7. Munby, J.L. Communicative Syllabus Design. Cambridge, Cambridge University Press, 1978.

8. Nuttall, N. Teaching Reading Skills in a Foreign Language. Cambridge, Cambridge University Press, 1982.

9. Swales, J. Genre Analysis: English In Academic and Research Settings. Cambridge, Cambridge University Press, 1990.

10. Trimble, L. English for Science and Technology: a Discourse Approach. Cambridge, Cambridge University Press, 1982,

11. Widdowson. H.G. Learning Purpose and Language Use. Oxford, Oxford University Press, 1983.

\section{3w24tunцnıpjnıl qnt_nı \\ Ltqumlqua hưunnıpjntaGitph qunqugưua znıp2}

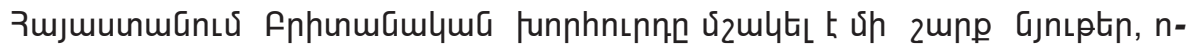

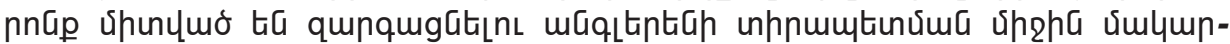

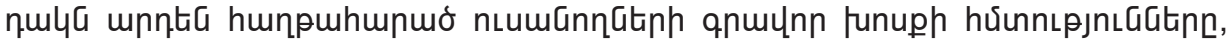

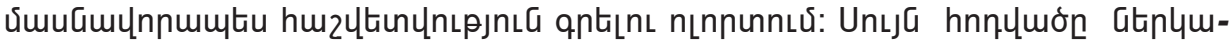

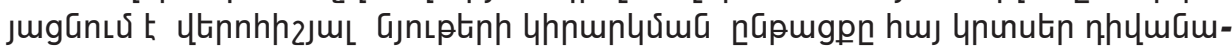

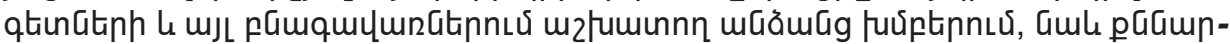

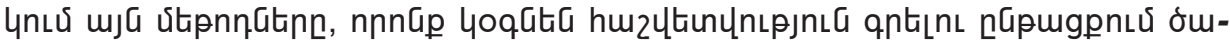

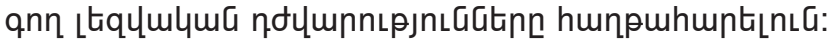

